Kwartalnik Młodych Muzykologów UJ

nr 45 (2/2020), s. 23-39

DOI 10.4467/23537094KMMUJ.20.010.12852

www.ejournals.eu/kmmuj

\title{
Klaudia Popielska
}

Uniwersytet im. Adama Mickiewicza w Poznaniu

\section{Sylwetka twórcza Aleksandra Zarzyckiego - zapomnianego kompozytora doby romantyzmu}

\section{Abstract}

The Artistic Profile of Aleksander Zarzycki: A Forgotten Composer of the Romantic Era

The second half of the 19th century in the history of Polish music is a neglected period, both in the aspect of performance and the aspect of research on this music. Unfortunately, works of many composers from this period have been forgotten. One of such composers is undoubtedly Aleksander Zarzycki (1834-1895), a composer, teacher, virtuoso pianist; the author of over 40 opuses and the composer of many solo songs with piano accompaniment, which were often compared to the songs of Stanisław Moniuszko. Similarly to the most famous Polish composer of songs, Zarzycki created two songbooks that are part of the trend of egalitarian songs. He was also renowned for his short piano pieces, written in a salon style with virtuoso elements. One of his most famous works was the Mazurka in $G$ major, which was popularised by the Spanish virtuoso violinist Pablo 
Sarasate. Also noteworthy is his Piano Concerto in A flat major Op. 17, referring to the Piano Concerto in A minor by Fryderyk Chopin and the Concerto in $\mathrm{G}$ minor by Józef Wieniawski. Zarzycki's works are characteristic of his era, including references to folklore, national style, virtuosity and the socalled "Romantic mood".

\section{Keywords}

Aleksander Zarzycki, Polish music of the 19th century, piano works, solo songs

Okres drugiej połowy XIX wieku na ziemiach polskich był niewątpliwie trudnym czasem. Już w 1795 roku, po trzecim rozbiorze, Rzeczpospolita przestała istnieć, przechodząc zapaść polityczną i kulturową, które nasiliły się po zakończonych klęską dwóch powstaniach - listopadowym w 1830 roku i styczniowym w 1863 roku. Nic więc dziwnego, że również rozwój kultury muzycznej na ziemiach polskich był wówczas znacznie utrudniony, a wiele dzieł z tamtego okresu nie przetrwało do dzisiaj, często ulegając zniszczeniom w wyniku działań wojennych. Warto również zwrócić uwagę na fakt, że pod zaborami perspektywy rozwojowe - zarówno sztuki, jak i nauki - różniły się od siebie. Największą autonomię twórcy posiadali pod zaborem galicyjskim, niewiele mniejszą pod zaborem pruskim, najmniejszą zaś pod zaborem rosyjskim.

Jak słusznie zauważa Irena Poniatowska we Wstępie do Historii Muzyki Polskiej. Romantyzm 1850-19oo', muzyka polska drugiej połowy XIX wieku jest dość zaniedbana, zarówno pod względem wykonawczym, jak i badawczym. Autorka, poza zasygnalizowaną już trudną sytuacją polityczno-kulturalną na ziemiach polskich, jako problem wskazuje brak dostępności materiałów nutowych, a właściwie brak ich opracowań edycyjnych, skutkujący niemożnością wykonywania tych dzieł oraz podejmowania szerszych refleksji badawczych. Mimo upływu dziesięciu lat od wydania wspomnianej wyżej publikacji, spostrzeżenia muzykolog w dalszym ciągu pozostają aktualne. Twórczość muzyczna kompozytorów okresu późnoromantycznego wydaje się wciąż niedostatecznie szczegółowo zgłębiona. Problem ten dotyczy zarówno znanych kompozytorów polskich - na przykład Zygmunta

1 I. Poniatowska, Historia Muzyki Polskiej. Tom V. Romantyzm, część druga A. Twórczość muzyczna $w$ drugiej połowie XIX wieku, 1850-19oo, Sutkowski Edition, Warszawa 2010, s. 57. 
Noskowskiego czy Władysława Żeleńskiego, których nie wszystkie dzieła zostały w pełni zbadane lub w ogóle wydane - jak również kompozytorów mniej znanych, których twórczość bardzo często nawet w niewielkim stopniu nie została poddana analizom. Niewątpliwie jednym z zapomnianych kompozytorów polskich drugiej połowy XIX wieku jest Aleksander Zarzycki. Zasłynął on głównie jako twórca pieśni solowych z towarzyszeniem fortepianu, miniatur fortepianowych oraz wirtuozowskich dzieł skrzypcowych. Jest to twórczość, której z jednej strony można przypisać epigonizm (naśladowanie dzieł Moniuszki czy Chopina), z drugiej jednak nie brak jej cech indywidualnych tak przecież charakterystycznych dla epoki romantyzmu. Niezaprzeczalnie więc dorobek twórczy Zarzyckiego stanowi istotną pozycję w skarbnicy polskiej kultury muzycznej XIX wieku.

O zapomnieniu twórczości, jak i samej postaci Aleksandra Zarzyckiego, może świadczyć ciągle niedostateczna liczba prac badawczych poświęconych dorobkowi twórczemu tego artysty. Wyjątek stanowi tutaj praca magisterska z 2018 roku dotycząca wybranych pieśni solowych $\mathrm{z}$ towarzyszeniem fortepianu Zarzyckiego ${ }^{2}$ oraz wzmiankowanie jego twórczości w różnego rodzaju encyklopediach, m.in. w Encyklopedii muzycznej $P W M^{3}$, a także w pracach poświęconych zagadnieniom późnoromantycznej muzyki polskiej. Wiele z dzieł tego kompozytora nadal pozostaje jedynie w postaci rękopisów, które nierzadko nie pojawiają się nawet w ogólnych wykazach twórczości kompozytora ${ }^{4}$. Mimo to jednak w ostatniej dekadzie można zaobserwować rosnące zainteresowanie twórczością Zarzyckiego, chociażby na gruncie wydawniczym ${ }^{5}$. Utwory te również przeżywają swój renesans wykonawczy. Znaczną część dzieł kompozytora możemy odnaleźć w propozycjach programowych dla pierwszego

2 K. Popielska, Pieśni solowe z fortepianem Aleksandra Zarzyckiego do słów Heinricha Heinego i Adama Asnyka w kontekście tradycji solowej pieśni romantycznej, praca magisterska napisana pod kierunkiem prof. UAM dr hab. J. Humięckiej-Jakubowskiej, Instytut Muzykologii Uniwersytetu im. Adama Mickiewicza w Poznaniu, Poznań 2018.

3 B. Chmara-Żaczkiewicz, Aleksander Zarzycki, w: Encyklopedia muzyczna PWM. Czesść biograficzna, t. 12, red. E. Dziębowska, PWM, Kraków 2012.

4 Pojedyncze utwory Zarzyckiego, które nigdy nie były wydane można spotkać m.in. w archiwum biblioteki Uniwersytetu Jagiellońskiego oraz w archiwum muzykaliów świętolipskich.

5 Wydania niektórych dzieł fortepianowych oraz kameralnych Zarzyckiego podjęło się w ostatnich latach gdyńskie wydawnictwo Eufonium. 
i drugiego etapu Międzynarodowego Konkursu Muzyki Polskiej im. Stanisława Moniuszki w Rzeszowie, zarówno w kategorii pianistów, jak i zespołów kameralnych ${ }^{6}$.

\section{Aleksander Zarzycki - rys biograficzny}

Aleksander Zarzycki urodził się 26 lutego 1834 roku we Lwowie. Ukończył gimnazjum w Samborze. Edukację muzyczną rozpoczynał pod okiem swojego ojca - amatorskiego skrzypka. Dalsze nauki pobierał u takich mistrzów, jak Joseph Christoph Kessler, Rudolf Viole czy Napoléon Henri Reber. Podjął również uzupełniające studia w zakresie kompozycji oraz gry na fortepianie w 1860 roku w Lipsku, ucząc się u Carla Reineckego ${ }^{7}$.

Zarzycki na początku swojej kariery zasłynął głównie jako pianista. Swoje pierwsze studenckie tournée odbył wraz ze skrzypkiem Nikodemem Biernackim w 1856 roku, mając dwadzieścia dwa lata. Muzycy zagrali wówczas m.in. w Jassach na terenach Rumunii, w Poznaniu oraz trzykrotnie w Krakowie ${ }^{8}$. Swój pierwszy, poważny koncert Zarzycki zagrał 30 marca 1860 roku w stolicy Francji, w Sali Herza. W repertuarze koncertowym znalazły się wówczas utwory autorskie Zarzyckiego, takie jak Koncert fortepianowy op. 17, Grande polonaise op. 7, a także kompozycje Fryderyka Chopina oraz Adolfa von Henselta. W 1862 roku, po swoim udanym koncercie we Francji, Zarzycki rozpoczął serię koncertów, z których pierwsze odbyły się w Koblencji, Wiesbaden, Dreźnie, kolejne w Lipsku w Sali Gewandhaus (w 1863) oraz w Bonn i Kolonii (w 1864). W tym okresie kompozytor-pianista koncertował również w Polsce, m.in. we Wrocławiu (4 lutego 1865), a także dwukrotnie w Poznaniu (6 lutego w Sali Bazaru oraz 22 lutego w Teatrze Miejskim). Trzy lata później (w 1868) Zarzycki odwiedził także ze swym programem koncertowym Londyn i Wiedeń. Jego koncerty cieszyły się wielkim uznaniem wśród publiczności, o czym może poświadczyć fragment wypowiedzi Marii Zduniak, dotyczący jednego $\mathrm{z}$ wrocławskich koncertów kompozytora:

6 Szczegóły dotyczące programu konkursu można odnaleźć na stronie internetowej: konkursmuzykipolskiej.pl [dostęp 23.10.2020].

7 B. Chmara-Żaczkiewicz, dz. cyt., s. 332.

8 Tamże. 
Koncert ten, prezentujący wszechstronne umiejętności Zarzyckiego, sprawił sporo satysfakcji słuchaczom. Artysta okazał się znakomitym pianistą, a zdziwienie wywołał fakt, że wykonywał cały program z pamięci. Jego talent pianistyczny i umiejętności kompozytorskie znalazły słowa szczerego uznania u recenzentów ${ }^{9}$.

Szczególnie chętnie Zarzycki włączał do repertuaru swoich koncertów muzykę mistrzów XIX wieku. Poza wspomnianymi już kompozycjami Chopina oraz Henselta, wśród utworów grywanych przez kompozytora znajdowały się także m.in. XIII Rapsodia wegierska oraz Rapsodia hiszpańska Franza Liszta, kompozycje Roberta Schumanna, Franza Schuberta, Ludwiga van Beethovena czy Antona Rubinsteina ${ }^{10}$.

Liczne podróże sprzyjały nawiązywaniu przez kompozytora nowych znajomości. Zarzycki miał okazję obcować $\mathrm{z}$ wielkimi europejskimi talentami, wśród których wymienić można: Liszta, wspomnianych już wcześniej Rebera oraz Reineckego, a także braci Rubinstein oraz Pabla Sarasatego - hiszpańskiego skrzypka i kompozytora. Bez wątpienia styczność z tak ważnymi dla świata muzyki osobistościami miała bezpośredni wpływ na wyrobienie przez Zarzyckiego specyficznego stylu muzycznego, w którym jednak nie brakowało cech indywidualnych ${ }^{11}$. Warto również wspomnieć, że Zarzycki prócz możliwości obcowania ze światowej sławy kompozytorami, miał okazję poznać osobiście także wybitnych polskich poetów, których twórczość znajdowała swoje zastosowanie w pieśniach kompozytora. Od około 1851 roku, przez kilkanaście lat, Zarzycki bywał stałym gościem w Miłosławiu, w majątku hrabiego Seweryna Mielżyńskiego. Dom hrabiego był ważnym ośrodkiem życia artystycznego w Wielkopolsce. Zarzycki miał okazję poznać tam m.in. takich poetów jak Teofil Lenartowicz, Władysław Syrokomla oraz Józef Ignacy Kraszewski ${ }^{12}$.

W 1866 roku Zarzycki zamieszkał na stałe w Warszawie. Ograniczył wówczas występy koncertowe, by oddać się w pełni pracy kompozytor-

9 W. Żeleński, Aleksander Zarzycki: ze wspomnień osobistych, w: „Echo muzyczne, teatralne i artystyczne”, XII, red. J. Kleczyński, Warszawa 1895, s. 567.

10 J. Skarbowski, Sylwetki pianistów Polskich. Tom 1. Od Wincentego Lessla do Henryka Puchalskiego, Wydawnictwo Oświatowe Fosze, Rzeszów 1996, s. 111-114.

11 W. Żeleński, dz. cyt., s. 566.

12 J. Mechanisz, Poczet kompozytorów polskich, Wydanie drugie poszerzone, Wydawnictwo Polihymnia, Lublin 2004, s. 142-143. 
skiej oraz pedagogicznej ${ }^{13}$. Kompozytor odegrał ogromną rolę w procesie rozkwitu życia artystycznego XIX-wiecznej Warszawy. W latach 1871-1874 pełnił funkcję dyrektora artystycznego nowo powstałego Warszawskiego Towarzystwa Muzycznego, którego był współzałożycielem. Jego działalność w WTM-ie była niezwykle istotna dla tej instytucji. Za sprawą Zarzyckiego utworzono siedzibę towarzystwa w salach redutowych Teatru Wielkiego w Warszawie, gdzie już po miesiącu działalności odbył się pierwszy, większy koncert muzyczny. $\mathrm{Z}$ czasem grywanie takich koncertów stało się tradycją. W 1871 roku kompozytor utworzył także chór mieszany, którego dyrygentem był do 1875 roku, a w 1872 roku powołał do działania orkiestrę smyczkową. Aleksander Zarzycki założył także w 1874 roku wydawnictwo nutowe WTM, w którym pierwszym opublikowanym dziełem był wyciąg fortepianowy Sonetów krymskich Stanisława Moniuszki. W 1875 roku został zmuszony zrezygnować z pełnienia funkcji dyrektora WTM-u, o czym zadecydowały władze rosyjskie, nietolerujące austriackiego obywatelstwa kompozytora. Nowym dyrektorem organizacji został wówczas Józef Wieniawski. Po odejściu z WTM Zarzycki został kierownikiem chóru i orkiestry katedry św. Jana Chrzciciela w Warszawie, funkcję tę sprawował w latach $1879-1892^{14}$.

Po śmierci Apolinarego Kątskiego, za sprawą działań Rady Nadzorczej Instytutu Muzycznego w Warszawie, 13 września 1879 roku Zarzyckiemu powierzono stanowisko dyrektora tej uczelni. Kompozytor dążył do tego, by w Instytucie zapanowały europejskie standardy nauczania. W związku z tym wprowadził wiele reform, redagując na nowo programy wszystkich kursów. Zmiany objęły m.in. program klasy fortepianu, w której wprowadzono obowiązek grania dzieł Jana Sebastiana Bacha, etiud Carla Czernego, Hermanna Berensa, Theodora Kullaka i Stephena Hellera. Dzięki staraniom Zarzyckiego w Instytucie zaczęli nauczać m.in. Ignacy Jan Paderewski oraz Stanisław Barcewicz. Nowo wybrany dyrektor zajął się z kolei prowadzeniem zajęć „ćwiczeń zbiorowych muzyki”, szkolnej orkiestry oraz wyższej klasy fortepianu. Dodatkowo Zarzycki organizował poza zajęciami wieczory muzyczne, w których mogli zaprezentować się zarówno studenci, jak i wykładowcy. Zastrzegał on sobie jednak prawo do zatwierdzania re-

13 W. Żeleński, dz. cyt., s. 568.

14 A. Spóz, Warszawskie Towarzystwo Muzyczne, w: Kultura muzyczna Warszawy drugiej połowy XIX wieku, red. tenże, PWN, Warszawa 1980, s. 42-54. 
pertuaru, który miał być wykonywany podczas koncertów (akceptował tylko te utwory, które jego zdaniem były wartościowe) ${ }^{15}$.

Zarzycki opierał się postępującej rusyfikacji uczelni, przez co wielokrotnie narażał się organom władzy. W roku akademickim 1887/1888 został zmieniony statut uczelni, w którym zawarto rozporządzenie dotyczące likwidacji przedmiotów prowadzonych w języku polskim oraz wymóg mówiący o tym, że dyrektorem uczelni musiała być osoba w pełni poddana władzy rosyjskiej i posiadająca rosyjskie obywatelstwo. Tym samym Zarzycki, posiadający obywatelstwo austriackie, został zmuszony do rezygnacji z posady dyrektora Warszawskiego Instytutu Muzycznego ${ }^{16}$.

Pod koniec lat 8o. XIX wieku zaczął poważnie chorować. Jednak jeszcze w 1888 roku przyjąl honorowe członkostwo Warszawskich Teatrów Rządowych i nadal występował. Swój ostatni koncert kompozytor zagrał w marcu 1895 roku w warszawskim ratuszu. Tego samego roku, 1 listopada zmarł, a kilka dni później został pochowany na cmentarzu Powązkowskim ${ }^{17}$.

\section{Twórczość Aleksandra Zarzyckiego}

Twórczość Zarzyckiego obejmuje ponad 40 opusów oraz kilka dzieł nienumerowanych, pośród których znajdują się utwory orkiestrowe, kameralne, przeznaczone na fortepian solo, pieśni na czterogłosowy chór oraz pieśni na głos i fortepian. W zbiorze zawierają się także trzy kantaty oraz opracowanie pieśni Boże coś Polskę na fortepian ${ }^{18}$.

Kompozycje te prezentują zróżnicowany poziom artystyczny (możemy odnaleźć wśród nich zarówno krótkie i nieskomplikowane miniatury salonowe, jak i rozbudowane utwory wirtuozowskie).

15 A. Rutkowska, Nauczanie muzyki w Warszawie w drugiej połowie XIX w. (1861-1918), w: Kultura..., dz. cyt., s. 17-33. Przez swoje obiekcje co do niektórych repertuarów koncertowych, które miały być wykonywane podczas „wieczorów muzycznych”, Zarzycki naraził się na niechęć ze strony części swoich kolegów - wykładowców. W efekcie w późniejszym czasie Zarzycki nie mógł już organizować koncertów na terenie uczelni, zaczął więc zapraszać na „wieczory muzyczne” wszystkich zainteresowanych do swojego własnego domu.

16 Tamże.

17 J. Skarbowski, dz. cyt., s. 112.

18 B. Chmara-Żaczkiewicz, dz. cyt., s. 332. 
Niektóre z nich nawiązują do twórczości innych kompozytorów (głównie Moniuszki i Chopina), inne przepełnione są zindywidualizowanymi środkami. Muzykolog Józef Reiss opisuje twórczość Zarzyckiego w następujący sposób:

\begin{abstract}
Znamionuje [ona] polskość, wykwintna forma i smak wytworny oraz szlachetny liryzm. Charakterystyczną formą jego muzyki fortepianowej jest miniatura pełna polotu i wdzięku, subtelna w harmonii, jest to muzyka salonu w najlepszym tego słowa znaczeniu ${ }^{19}$.
\end{abstract}

\title{
Utwory wokalne
}

Największą część dorobku artystycznego Aleksandra Zarzyckiego niewątpliwie stanowiły pieśni, zwłaszcza solowe. Kompozytor skomponował ich blisko 6o. Z jednej strony pieśni Zarzyckiego bywały krytykowane, m.in. za błędną akcentuację języka czy za niewłaściwie zastosowany kontrapunkt ${ }^{20}$. $Z$ drugiej jednak strony pieśni solowe można uznać za warte zauważenia i nieodbiegające walorami artystycznymi od np. pieśni moniuszkowskich ${ }^{21}$. W czasach współczesnych Zarzyckiemu były to utwory, które spotykały się $\mathrm{z}$ wielką aprobatą publiczności. W pieśniach tych odbiorcy cenili sobie proste melodie, wyrazową rolę akompaniamentu oraz wykorzystywane teksty poetyckie. Wielką popularność zyskała m.in. Między nami nic nie było, pochodząca ze Śpiewnika na jeden głos op. 13. Pieśn tę szczególnie rozsławiła polska śpiewaczka Marcelina SembrichKochańska, wykonująca ją w Europie oraz Stanach Zjednoczonych ${ }^{22}$. Wielkie walory artystyczne w pieśniach Zarzyckiego dostrzegał m.in. serdeczny przyjaciel kompozytora - Władysław Żeleński, piszący po śmierci artysty o jego pieśniach w następujący sposób:

Z całego dorobku artystycznego śp. Aleksandra, najwyżej cenimy pieśni, które wzbogaciły naszą literaturę muzyczną prawdziwymi perłami natchnienia. $\mathrm{W}$ nich okazał się Zarzycki prawdziwym poetą (...). To istotne diamenciki,

19 W. Żeleński, dz. cyt., s. 569.

20 W. Poźniak, Pieśn solowa po Moniuszce, w: Z dziejów polskiej kultury muzycznej t. 2. Od oświecenia do Młodej Polski, red. A. Nowak-Romanowicz, PWM, Kraków 1966, s. 452.

21 B. Chmara-Żaczkiewicz, dz. cyt., s. 334.

22 Tamże. 
w których blask i oprawa artystyczne sprawiają wrażenie. Wszystko w nich wytworne i szlachetne ${ }^{23}$.
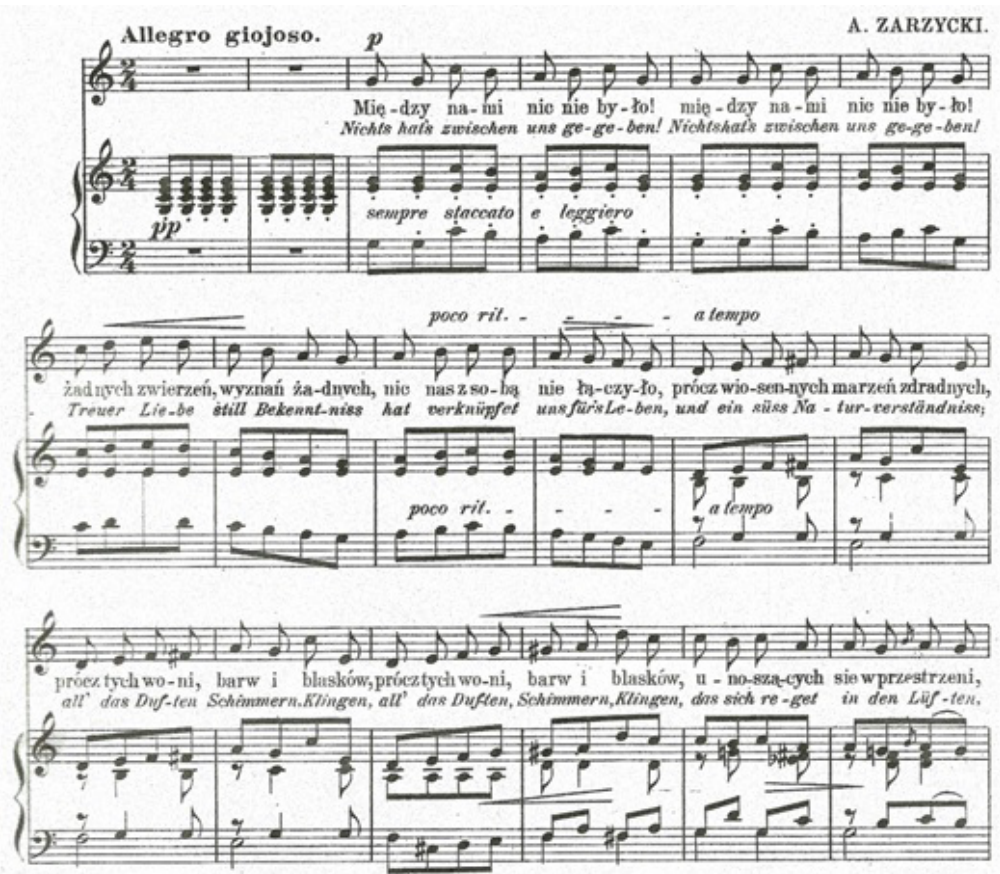

Przykład 1. A. Zarzycki, Między nami nic nie było, t. 1-18

Czasy, w których Zarzycki tworzył swoje pieśni, przypadają na dwie fazy rozwojowe pieśni polskiej ${ }^{24}$. W myśl podziału, jaki proponuje Mieczysław Tomaszewski, utwory Zarzyckiego należy zaklasyfikować do fazy szczytowo-romantycznej (pieśni op. 2 i op. 9) oraz do fazy późnoromantycznej (pozostałe kompozycje) ${ }^{25}$. Jednak mimo czasowej (uwzględniającej daty powstania) przynależności pieśni do

23 W. Żeleński, dz. cyt., s. 569.

24 Mieczysław Tomaszewski w Pieśni polskiej „wieku uniesień”. Rekonesans, w: Topos narodowy w muzyce polskiej pierwszej połowy XIX wieku, t. 1, red. W. Nowik, Akademia Muzyczna im. F. Chopina, Warszawa 2006 - przedstawia pięć faz rozwojowych romantycznej pieśni polskiej, są to kolejno fazy: preromantyczna, wczesnoromantyczna, szczytowo-romantyczna, późnoromantyczna oraz postromantyczna.

25 Por. M. Tomaszewski, Pieśń polska „wieku uniesień”..., dz. cyt. 
poszczególnych faz, wszystkie utrzymane są w jednorodnej stylistyce, nawiązującej do szczytowo-romantycznych dzieł.

Zarzycki tworzył pieśni do tekstów poetów cieszących się wielką sławą, jak i do tekstów poetów nieznanych, do tekstów poetów rodzimych oraz zagranicznych. Najczęściej jednak w swoich pieśniach wykorzystał teksty Adama Asnyka (16 pieśni) oraz Heinricha Heinego (6 pieśni). Tematyka pieśni Zarzyckiego w pełni wpisywała się w ówczesne tendencje. Jest to repertuar skupiony wokół tematyki miłosnej, nierzadko sprzęgniętej z wątkami patriotycznymi i dodatkowo sielskimi akcentami (liczne opisy przyrody, wątki wiejskiej obyczajowości). Swoje pieśni kompozytor pisał jako utwory samodzielne (nie można mówić tutaj o swego rodzaju pieśniach cyklicznych, jak np. u Schuberta), które w większości były łączone w większe zbiory, zawierające po kilka utworów. Najobszerniejszymi zbiorami pieśni Zarzyckiego były dwa Śpiewniki na jeden głos op. 13 i 14, w których daje się zaobserwować świadome nawiązanie do Śpiewników domowych Stanisława Moniuszki, mających charakter egalitarny ${ }^{26}$.

Poza pieśniami solowymi w repertuarze Zarzyckiego można odnaleźć także pieśni chóralne, przeznaczone na czterogłosowy chór. Można wśród nich wymienić Pieśn nocnego wędrowca do poetyckiego przekładu Aleksandra Michaux (w oryginalnej wersji językowej wiersz został napisany przez Johanna Wolfganga Goethego) oraz zbiór dwóch pieśni - Dwa śpiewy, na który składają się Chór strzelców do słów Stefana Floriana Garczyńskiego oraz Z łąk i pół do słów Marii Konopnickiej. Kompozytor napisał także dwie religijne pieśni w opracowaniu chóralnym - Veni creator oraz Salve Regina ${ }^{27}$. Dziełami wokalnymi Zarzyckiego są również trzy kantaty: Hymn do muzyki na chór mieszany, instrumenty dęte i harfę, Chór myśliwych na cztery głosy męskie, fortepian i dwa rogi oraz Serenadę na sopran, fortepian i orkiestrę. To utwory, które występują w ogólnych spisach dzieł Zarzyckiego, jednak samo dotarcie do materiału nutowego jest zadaniem niezwykle trudnym, tym samym - precyzyjne określenie walorów estetycznych i samych struktur tych pieśni - pozostaje nadal kwestią, którą należy zbadać ${ }^{28}$.

26 B. Chmara-Żaczkiewicz, dz. cyt., s. 334 .

27 J. Mechanisz, dz. cyt., s. 142.

28 B. Chmara-Żaczkiewicz, dz. cyt., s. 333. 


\section{Miniatury fortepianowe}

Zdecydowaną większość kompozycji Aleksandra Zarzyckiego obok pieśni solowych stanowią utwory fortepianowe. Muzyka polska drugiej połowy XIX wieku obfitowała w tego typu repertuar, głównie za sprawą ekspansji fortepianu jako instrumentu muzycznego, który stawał się coraz bardziej popularny nie tylko w wielkich salach koncertowych, lecz również w małych salonach. Co więcej, można stwierdzić, że fortepian stał się niejako przekaźnikiem całej literatury muzycznej w XIX wieku (bardzo często także utwory orkiestrowe były przepisywane np. na dwa fortepiany). Instrument ten pozwalał twórcom na doskonałe odzwierciedlenie intymnych przeżyć, m.in. poprzez możliwość zróżnicowania kolorystyki dźwiękowej oraz dynamiki.

W repertuarze Zarzyckiego odnaleźć możemy wiele reprezentatywnych dla jego czasów gatunków muzyki fortepianowej. Są to głównie mazurki - Deux Mazurkas op. 12, 20 i 36, Mazurek E-dur op. 38 - nawiązujące do utworów Chopina. Innym przykładem form tanecznych $\mathrm{w}$ utworach fortepianowych Zarzyckiego są jego walce - Wielki walc g-moll op. 4, Walc brillante As-dur op. 8 oraz Wielki walc D-dur op. 18 - w których nie brak elementów wirtuozowskich. Ponadto wśród dzieł fortepianowych kompozytora odnaleźć można także przykłady miniatur lirycznych, m.in. nokturny (Deux nocturnes op. 10), pieśni bez słów (Deux Chant Sans paroles op. 6), serenadę (Serenade As-dur z op. 24) oraz wiele innych.

O wspomnianej Serenadzie tak wypowiedział się na łamach „Echa Muzycznego" sam Antoni Sygietyński:

\footnotetext{
Serenada, utwór czysto fortepianowy, jest cackiem poezji erotycznej, pełnej wdzięku i prostoty. Na tle harmonii spokojnej, melodia uczucia namiętnego rysuje się jasno. Dwa takty ritorneli, zręcznie wplecione trzy razy w całość, nadają temu utworowi formę oryginalną i niezmiernie wykwintną. Miłość tchnie tu z każdego taktu, z każdego tonu, ale miłość szlachetna, bez sentymentalizmu ckliwego i bez żadnej przesady w wyrażeniu uczucia ${ }^{29}$.
}

Rzeczywiście jest to utwór o niezbyt skomplikowanej strukturze, jednak zdaje się on idealnie spełniać założenia, które implikuje już sama nazwa. Serenada była bowiem rodzajem pieśni miłosnej wykonywanej

29 J. Kleczyński (red.), „Echo Muzyczne”, nr 38, wyd. A. Rajchman, Warszawa 1884. 
przy akompaniamencie (najczęściej) gitary pod oknem ukochanej. Również w Serenadzie Zarzyckiego odnajdziemy środki nawiązujące do tej tradycyjnej formy. Prosty, akordowy akompaniament, któremu towarzyszy artykulacja arpeggio - mająca z pewnością budzić jasne skojarzenia z grą na gitarze - jest idealnym tłem do lirycznej, kantylenowej melodii, rozwijającej się ponad warstwą akompaniamentu.

Chcąc krótko podsumować twórczość fortepianową Zarzyckiego, należałoby w pierwszej kolejności wskazać na mocno zaakcentowany liryzm w kompozycjach. Jeśli zaś chodzi o sam czynnik melodyczny charakteryzuje się on specyficzną śpiewnością, która przeplatana jest $\mathrm{z}$ elementami wirtuozowskimi.

\section{Utwory kameralne}

Bez wątpienia miniatury fortepianowe oraz pieśni solowe były gatunkami najczęściej podejmowanymi przez kompozytorów polskich w drugiej połowie XIX wieku (tych dzieł zachowało się bowiem najwięcej do czasów współczesnych). Wynikało to z m.in. z mniejszych wymagań wykonawczych. Zgromadzenie małych zespołów kameralnych, a tym bardziej wielkich orkiestr symfonicznych, często stanowiło duży problem w trudnych czasach narodu polskiego bez państwa. Mimo to jednak, możemy odnaleźć w literaturze muzycznej tamtego okresu również dzieła kameralne. Włodzimierz Poźniak w publikacji $Z$ dziejów polskiej kultury zauważa, że liczba utworów kameralnych na terenach Polski wcale nie była mała, a jedynie wiele $\mathrm{z}$ tych dzieł nie zachowało się do czasów współczesnych ${ }^{30}$. Udało się jednak przywrócić do obiegu muzycznego (i wydawniczego) niektóre dzieła kameralne polskich kompozytorów, m.in. utwory Antoniego Stolpego, Antoniego Rutkowskiego, Zygmunta Stojewskiego, a także samego Zarzyckiego ${ }^{31}$.

Wśród dzieł kameralnych Zarzyckiego wymienić można Romans E-dur op. 16, Deuxième mazurka E-dur op. 39 oraz Mazurek G-dur op. 26, a także dzieła, które pierwotnie skomponowane były jako orkiestrowe, jednak stworzono również ich wersje na mniejsze obsady

30 W. Poźniak, dz. cyt., s. 453.

31 Zainteresowanie na gruncie wykonawczym twórczością wymienionych kompozytorów można zaobserwować m.in. w programie wspomnianego już Międzynarodowego Konkursu Muzyki Polskiej (zob. przypis 6). Z kolei prym wydawniczy, dotyczący publikowania twórczości nieco zapomnianych już polskich kompozytorów, prowadzi wydawnictwo Eufonium (http://www.eufonium.pl/pl/). 
wykonawcze (Andante et Polonaise A-dur op. 23 na skrzypce i fortepian, Introduction et Cracovienne E-dur op. 35 na skrzypce i fortepian).

Jednym z najbardziej znanych dzieł Zarzyckiego jest Mazurek G-dur op. 26 na skrzypce i fortepian, który przyniósł kompozytorowi wielką popularność i uznanie. Jest to jeden $z$ kanonicznych utworów w dziejach literatury skrzypcowej. Skomponowany został w 1884 roku i zadedykowany Pablowi Sarasatemu. Ten wirtuozowski mazurek przypadł do gustu hiszpańskiemu skrzypkowi, który chętnie wykonywał go podczas bisów, tym samym przyczyniając się do spopularyzowania tego dzieła na skalę międzynarodową ${ }^{32}$.
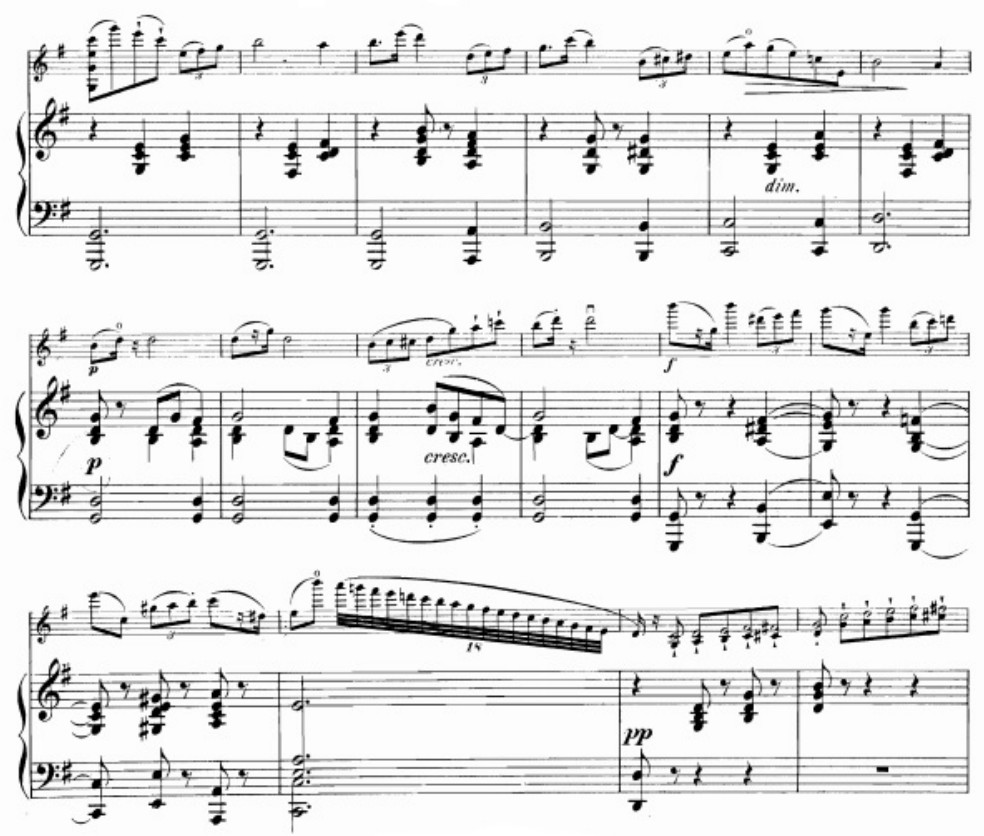

Przykład 2. A. Zarzycki, Mazurek G-dur op. 26, t. 7-22

Pod względem wysokiej popularności, wśród dzieł kameralnych Zarzyckiego - zaraz po Mazurku G-dur - należy wskazać Romans E-dur

32 J. Kusiak, Przewodnik po muzyce skrzypcowej, wydanie drugie, PWM, Warszawa 2014, s. 472. 
op. 16 na skrzypce i fortepian ${ }^{33}$. Został on opublikowany w 1875 roku przez niemieckie wydawnictwo Bote \& Bock. Jak można przeczytać w Przewodniku po muzyce skrzypcowej Jerzego Kusiaka:

\begin{abstract}
Romans, nie tak popularny jak Mazurek G-dur, jeszcze dziś ujmuje poetyckim nastrojem, szlachetną melodyką i niebanalną harmoniką. Utrzymany $\mathrm{w}$ nieskazitelnej formie, napisany został $\mathrm{z}$ wyczuciem instrumentu, $\mathrm{z}$ wykorzystaniem pełnej skali skrzypiec ${ }^{34}$.
\end{abstract}

\title{
Utwory orkiestrowe
}

Dzieła orkiestrowe powstawały stosunkowo rzadko na terenach polskich $\mathrm{w}$ drugiej połowie XIX wieku, z uwagi na niewielką liczbę funkcjonujących orkiestr. Kompozytorzy, którzy decydowali się na pisanie utworów przeznaczonych na orkiestrę, często mieli świadomość tego, że być może ich dzieła w czasach im współczesnych nie doczekają się wykonania w pełnej obsadzie orkiestrowej. Właśnie z tego względu wielu twórców decydowało się na przepisywanie swoich utworów orkiestrowych na składy kameralne. Taką praktykę bardzo często stosował również Aleksander Zarzycki, który część swoich utworów orkiestrowych przepisał także na skrzypce i fortepian oraz w przypadku Koncertu na dwa fortepiany.

Do utworów orkiestrowych Zarzyckiego należą: Uwertura uroczysta, Suita polska op. 37, Wielki polonez Es-dur op. 7 na fortepian i orkiestrę dedykowany Hansowi von Bülowowi, Andante et Polonaise A-dur op. 23 na skrzypce i orkiestrę oraz Introduction et Cracovienne D-dur op. 35 na skrzypce i orkiestrę. Są to dzieła silnie zaznaczające wartości idiomatyczne dla muzyki polskiej okresu popowstańczego, takie jak elementy narodowe. Odnaleźć je można już w samych tytułach dzieł (np. Suita polska), jak również w nawiązaniach do muzyki ludowej, m.in. poprzez włączanie do dzieł elementów polskich tańców narodowych (poloneza, mazura, krakowiaka).

Prawdopodobnie drugim pod względem popularności dziełem Zarzyckiego - zaraz po Mazurku G-dur - jest jego Koncert As-dur op.

33 W haśle „Aleksander Zarzycki” Encyklopedii muzycznej PWM można odnaleźć adnotację, że Romans E-dur przeznaczony był na kwartet dęty i skrzypce. Zob. B. Chmara-Żaczkiewicz, dz. cyt.

34 J. Kusiak, dz. cyt., s. 472. 
17 na fortepian i orkiestrę, dedykowany Mikołajowi Rubinsteinowi. $\mathrm{W}$ drugiej połowie XIX wieku, na terenach polskich, pierwszy koncert fortepianowy skomponował Józef Wieniawski (w 1858), z kolei drugi właśnie Aleksander Zarzycki. Jego premiera miała miejsce w Paryżu w 1860 roku, następnie kompozytor zagrał go w Warszawie, pierwszy raz w 1868 roku, kolejny - dwanaście lat później - w zmienionej wersji. Po pierwszej prezentacji koncertu przed publicznością warszawską w prasie pojawiła się recenzja polskiego pianisty i krytyka muzycznego - Jana Kleczyńskiego, której fragment brzmiał następująco:

Andante szlachetnie jest pomyślane i przeprowadzone. W finale pierwszy motyw mniej nam się podoba niż drugi; pasażowanie wdzięczne; zdaje się, że - lubo nie ma nigdzie wyraźnego podobieństwa - w duszy kompozytora unosi się obraz cudownego Koncertu f-moll Chopina ${ }^{35}$.

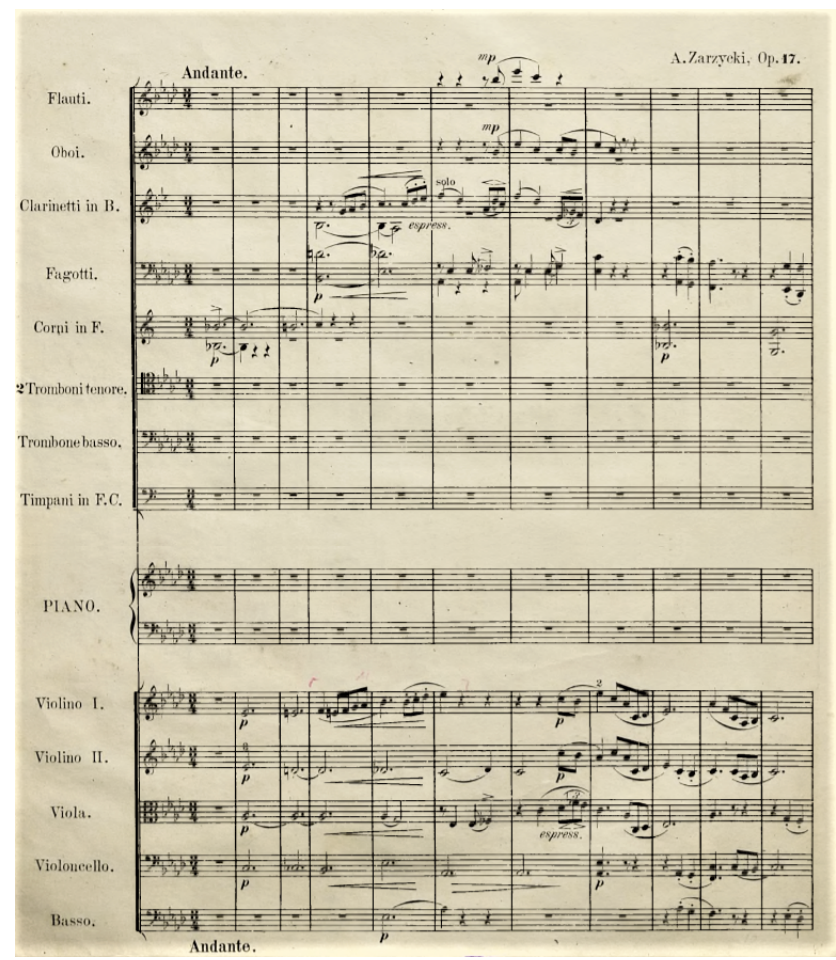

Przykład 3. A. Zarzycki, Koncert fortepianowy As-dur op. 17, t. 1-11

35 W. Żeleński, dz. cyt., s. 569. 
Koncert Zarzyckiego składa się z dwóch części: Andante w tonacji As-dur oraz Allegro non troppo w f-moll. Prawdopodobnie pierwotnie koncert był planowany jako dzieło trzyczęściowe. Pierwsza część koncertu przyjmuje formę nokturnu, w której zauważyć można kontrastującą część środkową opartą na recytatywie. Jest to bardzo długa część, mocno zaznacza się w niej rytmika krakowiaka. Podobnie jak w koncercie Wieniawskiego z 1858, Zarzycki zrezygnował w pierwszej części koncertu z pełnego tutti orkiestrowego. Druga część koncertu jest $\mathrm{z}$ kolei przykładem zastosowania formy allegra sonatowego. Charakterystyczne dla tego dzieła są wewnętrzna rozmaitość stylistyczna oraz subtelna instrumentacja ${ }^{36}$. Kompozytor zastosował również niebanalne rozwiązania harmoniczne, w których często występują dysonanse wraz ze skomplikowanymi połączeniami funkcyjnymi. Zbudował w swoim koncercie refleksyjny nastrój, m.in. poprzez skameralizowanie brzmienia i unikanie częstego tutti. Partia fortepianu, niepozbawiona figuracyjnej wirtuozerii, realizowana jest $\mathrm{z}$ kolei z zastosowaniem pełni możliwości brzmieniowych tego instrumentu ${ }^{37}$.

Koncert fortepianowy As-dur op. 17 Zarzyckiego, poza nim samym, wykonywali także inni pianiści-wirtuozi, m.in. Berthe Marx-Goldschmidt, Franciszek Bylicki, Józef Śmidrowicz oraz Władysław Kędra ${ }^{38}$.

$* * *$

Dorobek kompozytorski Zarzyckiego nie przyczynił się do wprowadzenia do muzyki polskiej wartości przełomowych. W twórczości kompozytora można odnaleźć liczne odwołania do dzieł Chopina, Moniuszki czy innych europejskich mistrzów. Kompozycje Zarzyckiego prezentowały bardzo zróżnicowany poziom artystyczny, przez co krytyka wobec jego dzieł bywała zarówno pochlebna, jak i nieprzychylna. Warto zaznaczyć, że prowadzone przez kompozytora tematy muzyczne charakteryzowały się liryczną melodyjnością, wzbogacaną elementami wirtuozowskimi, natomiast stosowane przez niego rozwiązania harmoniczne nie były w żaden sposób innowacyjne - mimo to na swój sposób brzmiały ciekawie. Jest to niewątpliwie twórczość, po którą warto sięgać, zarówno na gruncie wykonawczym, jak i prowadząc badania nad polską muzyką XIX-wieczną.

36 B. Chmara-Żaczkiewicz, dz, cyt., s. 333.

37 I. Poniatowska, dz. cyt., s. 477.

38 B. Chmara-Żaczkiewicz, dz. cyt., s. 333. 


\section{Bibliografia}

\section{Opracowania}

Chmara-Żaczkiewicz B., Aleksander Zarzycki, w: Encyklopedia muzyczna PWM. Część biograficzna, t. 12, red. E. Dziębowska, PWM, Kraków 2012.

Kleczyński J. (red.), „Echo Muzyczne”, nr 38, wyd. A. Rajchman, Warszawa 1884.

Kusiak J., Przewodnik po muzyce skrzypcowej, wydanie drugie, PWM, Warszawa 2014.

Mechanisz J., Poczet kompozytorów polskich, wydanie drugie poszerzone, Wydawnictwo Polihymnia, Lublin 2004.

Poniatowska I., Historia Muzyki Polskiej. Tom V. Romantyzm, część druga A. Twórczość muzyczna w drugiej połowie XIX wieku, 1850-19oo, Sutkowski Edition, Warszawa 2010.

Popielska K., Pieśni solowe z fortepianem Aleksandra Zarzyckiego do słów Heinricha Heinego i Adama Asnyka w kontekście tradycji solowej pieśni romantycznej, praca magisterska napisana pod kierunkiem prof. UAM dr hab. J. Humięckiej-Jakubowskiej, Instytut Muzykologii Uniwersytetu im. Adama Mickiewicza w Poznaniu, Poznań 2018.

Poźniak W., Pieśn solowa po Moniuszce, w: Z dziejów polskiej kultury muzycznej t. 2. Od oświecenia do Młodej Polski, red. A. NowakRomanowicz, PWM, Kraków 1966.

Rutkowska A., Nauczanie muzyki w Warszawie w drugiej połowie XIX w. (1861-1918), w: Kultura muzyczna Warszawy drugiej połowy XIX wieku, red. A. Spóz, PWN, Warszawa 1980.

Skarbowski J., Sylwetki pianistów Polskich. Tom 1. Od Wincentego Lessla do Henryka Puchalskiego, Wydawnictwo Oświatowe Fosze, Rzeszów 1996.

Spóz A., Warszawskie Towarzystwo Muzyczne, w: Kultura muzyczna Warszawy drugiej połowy XIX wieku, red. tenże, PWN, Warszawa 1980. Tomaszewski M., Pieśń polska „wieku uniesieñ”. Rekonesans, w: Topos narodowy w muzyce polskiej pierwszej połowy XIX wieku, t. 1, red. W. Nowik, Akademia Muzyczna im. F. Chopina, Warszawa 2006.

Żeleński W., Aleksander Zarzycki: ze wspomnień osobistych, w: „Echo muzyczne, teatralne i artystyczne”, XII, red. J. Kleczyński, Warszawa 1895. 
